\title{
The Relationship between Iranian EFL University Professors' Code Switching and their Characteristics such as Age, Gender and Educational Levels
}

\author{
Reza Nemati Moghadam \\ MA holder in TEFL, Islamic Azad University, Torbat Heidariyeh Branch, Iran \\ E-mail: nemati.khatesefid@gmail.com \\ Mohammad Davoudi (Corresponding Author) \\ Assistant Professor in TEFL, Department of English Language and Literature \\ Hakim Sabzevari University, Sabzevar, Iran \\ E-mail: davoudi2100@gmail.com
}

Received: November 5, 2015 Accepted: Dec. 7, 2015 Published: February 1, 2016

doi:10.5296/jse.v6i1.8605

URL: http://dx.doi.org/10.5296/jse.v6i1.8605

\begin{abstract}
The purpose of this study was to examine Iranian EFL university professors' code switching behavior in terms of variables such as age, gender and educational levels The participants of this study were 120 (64 males and 56 females) Iranian EFL university professors who were teaching English in different universities. A questionnaire was administered to examine the professors' attitude towards code switching in L2 classrooms. The questionnaire was followed by an open-ended interview to supplement the data.The results of this study gave credit to the usefulness of code switching strategies, especially interactive type of code switching in speaking. Also, it was found that the professors' age and educational levels could positively influence their use of code switching strategy whereas no significant relationship was found between code switching behaviour and gender.
\end{abstract}

Keywords: Code switching, professors' attitude, age, gender, educational levels 


\section{Introduction}

In bilingual and multilingual contexts, speakers alternate between languages or code switch when they speak. Bilinguals engage in code switching when they cannot or do not find appropriate words or phrases to express the intended meaning. This is called the most available word phenomenon. According to Moreno, Federmeier, \& Kutas (2002), code switching could be considered as "a change in language form, with the "same" meaning conveyed using a more available word that happens to be from the other language" (p. 189).

The term code switching is related to the alternation between two or more languages or dialects in the field of discourse between people who have a common language. It is not uncommon to see bilingual speakers mixing and shifting between two languages when they speak in different contexts Gulzar (2010). Teachers also code-switch when they teach in the classroom. Linguistic code switching in second or foreign language teaching was not a research field in the past; however, quite recently, code switching as received researchers' attention considerably (Gulzar, 2010).

Researchers and teachers of second or foreign language teaching have always been concerned to minimize code switching in the classroom. However, there is no empirical evidence to substantiate the claim that the exclusion of mother tongue in the process of teaching or learning a second or foreign language would necessarily improve learning efficiency. On the contrary, in the words of Eldrige (1996, p. 303), 'the majority of code switching in the classroom is highly purposeful and related to pedagogical goals".

Many researchers believe that correct language switching has powerful influence on and advantages for learners' communication. The earliest definition of code switching goes back to Weinreich (1953), which defines bilingual people as individuals who switch form one language to another on the basis of appropriate changes in speech situation. Code switching can take place in different forms such as alternation of sentences, phrases and linguistic or syntactic items. According to Skiba (1997), in normal conversation between two bilinguals, code switching consists of eighty-four percent single word switches, ten percent phrase switches, and six percent clause switching.

Some studies have shown that code switching can demote the progression of learners. For example, Cheng \& Bulter (1989) argues that "code switching could take away the purity of the language". Payawal-Gabriel \&Reyes-Otero (2006) claim that the practice of code switching in the classroom has negative effects on learning. Their analysis shows that teachers' code switching affects learners' comprehension. When teachers alter the codes, they decrease motivation in learner's competence.

Macaro (1997) has summarized the attitudes towards teacher code switching in language classrooms in three categories: virtually all, maximal, and optimal. He says the virtually all view is based on the view that the learners' first language (L1) has no value in the class and should be avoided by all means. By the same token, the maximal view rules out the role of L1 in foreign language classrooms, although its position in not as extreme as the position taken by the advocates of the virtually all view. Also, he believes optimal view holds the use of L1 
has pedagogical value and thus should be emphasized in the classroom. However, the consensus among the advocates of this perspective is that the use of L1 should not be uncontrolled and instead should be governed by optimal principles and guidelines informed by empirical research.

Using code switching in the classroom is a means for students to communicate and enhance their understanding. Hisham Ahmad \& Jusoff(2009)claims that teachers often code switch when the level of English used in the textbook or to be taught is beyond the learners' ability or when the exhausted teacher wants to adjust his speech to the learners' level. When students know the meaning of concepts or phrases, there should not be any code switching. They can understand the meaning of concepts. When students do not know the meaning of concepts, the use of code switching is essential. It enhances students' comprehension. Moreover, according to Hisham Ahmed \& Jusoff (2009), code switching enhances the flow of classroom instruction since teachers do not have to spend so much time to explain or search for the easiest words to clarify any confusion that might happen.

Accounts of code switching no longer consider code switching as a compensation for linguistic deficiency among bilingual speakers (Adendorff, 1996). On the contrary, code switching is regarded as a linguistic behavior motivated by functional considerations (Adendorff, 1996). The literature shows that code switching is an integral part of most language classrooms. What is striking is that little systematic research has been carried out on factors that lead language teachers to switch codes in the Iranian EFL context. The present study will seek to find out the relationship between Iranian EFL university professors' code switching and their characteristics such as age, gender and educational levels.

\subsection{Research Questions}

This study will focus on the attitudes of teachers towards code switching, examining the potential effects of teacher characteristics such as age, gender and educational levels on the use of code switching. Therefore, the following questions are raised in this study:

1. Is there any relationship between teachers' age and the frequency of EFL teachers' code switching?

2. Is there any relationship between teachers' gender and the frequency of EFL teachers' code switching?

3. Is there any relationship between teachers' educational levels and the frequency of EFL teachers' code switching?

\subsection{Research Hypotheses}

On the basis of the research questions mentioned above, three hypotheses are formulated in this study, which are as follows:

1. There is no relationship between teachers' age and the frequency of EFL teachers' code switching. 
2. There is no relationship between teachers' gender and the frequency of EFL teachers' code switching.

3. There is no relationship between teachers' educational levels and the frequency of EFL teachers' code switching.

\section{Review of Literature}

Gumperz, (1982) coined the term 'code switching' to refer to marked verbal or non-verbal choices of forms in a communicative encounter. Numan \& Carter (2001) defines the term as switching from one language to another in the same discourse. Although code switching has received considerable debate in the literature, the issue of linguistic code switching in foreign language classrooms has not been extensively studied. Zabrodskaja, (2007) holds that code switching has been largely addressed in the literature in terms of language transfer or a compensatory communicative strategy. However, code switching can be considered as an integral part of language learning and needs to be studied as such.

Code switching is defined as the alternation between two codes among people who share some special codes. The earliest definition of code switching dates back to Weinreich (1953). It defines bilingual people as individuals who switch from one language to another with respect to changes in speech situation. How code-switching appears itself, is settled by a number of social and linguistic factors (Auer, 2005, De Fina, 2007, Hill, 2009, Kabuto, 2010, Migge, 2007, Moore, 2002, Saxena, 2009, Wodak, 2012). It is common in multicultural and immigrant populations. According to Skiba (1997), code switching includes changing of sentences or phrases from both languages. In common conversations between two bilinguals, code switching includes eighty-four percent single word switches, ten percent phrases switches, and six percent clause switching (Skiba, 1997).

Code switching has mostly been studied in individual case studies. For example, Blom \& Gumperz (1972)which focused on code switching patterns in parts of Norway. Linguistic aspects of code switching have been addressed by Woolford, (1983), Di Sciullo, Muysken, \& Singh, (1986), and Poplack, (1980) which used natural discourse but few studies have examined code switching in the context of classroom interaction. This may be rooted in the fact that code switching in the classroom was long viewed negatively and was largely prevented because using the target language was to be maximized. However, in the 1990s, code switching was first explored as a contextualization.

In the second language acquisition (SLA) context, CS has turned out to be a complicated issue since the foreign language (FL) is both the means and the end of the classroom communication Qian, Tian \& Wang (2009). While in sociolinguistics CS has been described as a skilled performance, in SLA it has been traditionally looked upon as a symptom of error and lack of competence to the extent that the mixture of the first and the second language in the classroom has been considered "heterodox". One can look at this argument against classroom CS from both historical and socio-affective perspectives. From the historical viewpoint, some of the most widely used teaching methodologies, such as Direct method and Audiolingualism, have claimed that students' L1 must be suppressed in the classroom for the 
sake of better language learning. This claim is mainly based on two psycholinguistic justifications: the first one originates from an analogy between L1 and L2 learning implying that like children who acquire their first language without the help of any other linguistic code, L2 learners must experience the same situation if they want to be successful. Such an analogy, however, is based on a wrong comparison because L2 learners have an already built linguistic system (which is not possessed by L1 learners) and, therefore, they can use it as an asset throughout their L2 learning process (Greggio\& Gil, 2007).

With respect to language teachers, a quick look at the history of language teaching indicates that CS has been considered a pedagogical instrument in the hand of teachers despite the criticisms that have been traditionally waged against the use of students' L1 in the classroom(Cook, 2001). Teachers have used it as an interactional resource (Mugla \& Seedhouse, 2005)and an effective pedagogical tool (Turnbull \& Arnet, 2002)to achieve their desired goals. It seems that the time has come to abandon repressive measures against teachers' use of L1 and instead try to look for its pedagogical implications.

Ariffin \& Hussin (2011) explored the frequency of code switching as well as teachers' and students' attitudes towards code switching. They used self-completed questionnaires and interviews and found that teachers frequently code switch between the two languages in the classroom. It was argued that the occurrence of code switching was due to teachers' and learners' competence and an intention to facilitate language learning and teaching. Iannacci (2008) examined the code switching behavior of culturally and linguistically diverse children in kindergarten and grade 1 classrooms. Using ethnographic date, the authors revealed that code switching enabled students to address their language and literacy needs and assert their identities.

Yao (2011) studied attitudes to teacher code switching in EFL classes. The results of their questionnaire illustrated that teachers and students both had similar positive attitudes to teacher's code switching in EFL classroom. Qing (2010) examined the code-switching practices of teachers of non-English majors. Qing argues that code-switching is not always a blockage or deficiency in learning a language. On the contrary, it could be considered as a useful strategy in classroom interaction if the aim is to make meaning clear and to transfer the knowledge to students in an efficient way. In other words, code switching can build a bridge from known to unknown and is a useful strategy when used efficiently.

Hisham Ahmad \& Jusoff (2009) studied the learners' perceptions of teachers' code switching in ELT classrooms. The study found learners' positive attitudes towards code switching and also found that there are relationships between teachers' code switching and learners' affective support and learners' learning success. Hamzehlou Moghadam et al. (2012) studied code switching as a medium of instruction in an EFL classroom. The study employed audio recordings of a classroom observation and students' reflective journals as research instruments. It was found that students code switch because of vocabulary deficiency as well as requirements of informal language contexts. The students engaged in code switching when they checked for understanding, asked for clarification and for socializing. The reason for teachers' code switching was found to be clarification requirements. 
Chimbganda \& Mokgwathi (2012) looked at code switching in senior secondary schools in Botswana. Using an ethnographic design, the study found that code switching is quite prevalent in content subjects, and is used as a pedagogic resource to clarify subject matter knowledge and to reduce the social distance between the teacher and learners. Lee (2010) studied code switching in ELT classroom of secondary school students in Malaysia. The findings illustrated that the majority of teachers have positive attitudes towards code switching. They only practiced code switching when there was a need. Teachers also believed that code switching facilitates second language learning. Becker (2001) investigated Spanish-English code switching in a bilingual academic context. Results suggest there is a positive relationship between code-switched story retelling, oral language usage, and enhanced narrative skills. It was also found that teachers use the use of code switching in a story retelling activity to enhance bilingual elementary students' verbal skills and reading development.

In the Iranian EFL context, Simin, Teimouri, Kasmaee, and Rezaei (2005) studied the role and the effects of code switching in material learning in a classroom context and also students' attitudes towards this linguistic phenomenon. For this purpose, the students' notes, which were taken from the teachers' speech, were studied and then their written notes were analyzed qualitatively with a focus on code switching. Then, a questionnaire was distributed among participants to investigate their attitudes. According to the quantitative and qualitative data obtained from the questionnaire distributed among 60 participants and the interview, code switching was very helpful in learning assisting the learners to remember better for their exams. Simin, Teimouri, Kasmaee, and Rezaei (2005) examined the typology of EFL teachers' codes switching and the results of data analysis indicated that the typology has external manifestations in teachers' instances of code switching. It was also discovered that, among the selected participants, L1 was mostly used to fulfill pedagogical functions rather than social ones. Similar results were found in another study conducted by Moradkhani (2012).

Another investigation was carried out by Rezvani \& EslamiRasekh (2011). This study presented the results of a small-scale exploratory investigation of code switching (CS) between English and Persian by 4 Iranian English foreign language (EFL) teachers in elementary level EFL classrooms in a language school in Isfahan, Iran. The findings suggest that CS is a frequently applied strategy and a valuable resource for bilingual teachers in foreign language classrooms, and its judicious and skillful use can boost the quality of teaching. Moreover, it was found that EFL teachers in this study tended to use the learners' L1 (i.e., Persian) to serve a number of pedagogic and social functions, which contributed to better teacher-student classroom interaction.

A study by Hancock (1997) conducted in an ESL class in Madrid and another study by Mori (2004) carried out in a Japanese class in America revealed the patterns of students' use of code switching in foreign language classrooms. Hancock (1997) concluded that the dichotomy between bad L1 use and good L2 use in a language classroom should be dismissed because code switching is a natural by-product of bilingualism. Based on her study, Mori (2004) suggested that the prevalent target-language use policy in language classrooms should 
be reconsidered and that code switching should be considered as a useful teaching and learning strategy. Finally, the present study is an attempt to explore the relationship between Iranian EFL university professors' code switching and their characteristics such as age, gender and educational levels.

\section{Method}

This study aims at examining the factors which contribute to the ways in which EFL teachers switch codes. Although the issue has been investigated in various domains with different groups of learners, the paucity of research on the determining factors which may motivate EFL teachers to switch codes is evident.

\subsection{Participants}

The participants of this study were 120 Iranian EFL university professors who were teaching English in different universities. The sample comprised both males $(n=64)$ and females $(n=$ 56) who were teaching at different language proficiency levels. The selection of the participants of this study was based on convenient sampling procedure since the lack of access to EFL professors imposed limitations on selecting the participants randomly. The participants did not have the same educational background.

The participants were teachers of English as a Foreign Language at BA and MA levels. The professors' native language was Persian. The age range of the professors was 30 to 55 in order to be able to examine the effect of age on their use of code switching strategies. They were selected from both genders in order for the researcher to be able to assess the impact of gender on code switching strategies as well. Finally, the educational level of the professors were MA or Ph.D. as one of the objectives of the study was to test the effect of educational level on the frequency of different code switching strategies used by EFL professors.

\subsection{Research Instruments}

\subsubsection{Teachers' Questionnaire}

A questionnaire was used to examine the professors' attitude towards code switching in L2 classrooms (see Appendix A). The questionnaire was adopted from Jingxia (2010). The questionnaire included eight items and it took about 10 minutes to complete. The first section elicits data on professors' personality. It asks professors' attitudes towards their code switching behavior in classroom management and interpersonal relations respectively. In another section, the questionnaire explores participants' attitudes to code switching used for subject access and provides data as to whether teachers' code switching is used for classroom management and the last section considers attitudes towards professors' code switching for interpersonal relations.

The responses to the questionnaire were analyzed quantitatively to examine the professors' perceptions of their code switching in EFL classes. The participant background information questionnaire was specifically designed to collect background information concerning the participants' gender, age and educational levels of their current position in university.It was 
assumed that the participants should have enough years of English learning experiences to be aware of their communication avoidance and tendencies in English.

\subsubsection{Open-ended Interview}

The questionnaire was followed by the administration of an open-ended interview embraced by volunteering professors. A series of questions were formulated to find out the professors' opinions concerning code switching in the classroom (Appendix B). To get as much out of the interviews as possible, we created a conversational situation in which the interviewees would feel comfortable and elaborate their answers even more. The interviews were recorded so that it would be easier to review them again and again for a full descriptive account. The interviews ran smoothly and without any time-pressure or disturbances. The lengths of the interviews were approximately 20 minutes each.

\subsection{Procedure}

Before the administration of the questionnaire, the researcher explained the purpose and objectives of the study to the participants and asked them to answer the questions honestly and carefully. It is worth noting that, in this study, the term code switching encompasses switching at inter-sentential and intra-sentential levels. The researcher also informed the participants that the participation was voluntary and their responses would be kept anonymous and confidential. After completing the questionnaires, the study was followed by semi-structured interviews administered to volunteer teachers from among participants. 45 volunteer participants were interested to participate in the interview. Hence, they were inteviewed and find out their opinions concerning code switching in the classroom.

\subsection{Data Analysis Techniques}

From the initial stage, certain procedures were followed in order to analyze the data in a holistic and logical way. The Statistical Package for Social Sciences (SPSS, Version 21.0) was used to conduct the descriptive analysis of the survey data. The study employed a questionnaire to answer the three research questions including 1) the relationship between professors' age and the frequency of EFL professors' code switching; 2) the relationship between professors' gender and the frequency of EFL professors' code switching; and 3) the relationship between professors' educational level and the frequency of EFL professors' code switching.

For the data analysis of the first research question, Pearson correlation was applied to see whether there is any relationship between teachers' gender and the frequency of EFL teachers' code switching. For the second research question, Pearson correlation was also used to figure out relationship between teachers' gender and the frequency of EFL teachers' code switching. For the third research question, another Pearson correlation was used to show the statistically significant relationship between teachers' educational levels and the frequency of EFL teachers' code switching. 


\section{Results}

\subsection{Addressing the First Research Hypothesis}

The descriptive statistics were used in order to investigate the first research hypothesis of this study. Table 1 provides the information of teachers' age.

Table 1. Teachers' age range

\begin{tabular}{ccccc}
\hline & Frequency & Percent & Valid Percent \\
\hline \multirow{3}{*}{ Valid } & $30-35$ years old & 15 & 10.2 & 10.2 \\
\cline { 2 - 5 } & $35-40$ years old & 35 & 30.2 & 30.2 \\
\cline { 2 - 5 } & $40-45$ years old & 54 & 47.5 & 47.5 \\
\cline { 2 - 5 } & $45-50$ years old & 16 & 12.1 & 12.1 \\
\cline { 2 - 5 } & Total & 120 & 100.0 & 100.0 \\
\hline
\end{tabular}

In order to investigate the first research hypothesis in finding whether there is any relationship between teachers' age and the frequency of EFL teachers' code switching, a Pearson correlation was performed. The results are presented in Table 2.

Table 2. Pearson correlation between teachers' age and the frequency of their code switching

\begin{tabular}{cccc} 
& & Age & $\begin{array}{c}\text { Teachers' code } \\
\text { switching }\end{array}$ \\
\hline \multirow{2}{*}{ Age } & Pearson Correlation & 1 & $.678^{* *}$ \\
\cline { 2 - 4 } & Sig. (2-tailed) & .000 \\
\hline \multirow{2}{*}{$\begin{array}{c}\text { Teachers' code } \\
\text { switching }\end{array}$} & Pearson Correlation & 120 & 120 \\
\cline { 2 - 4 } & Sig. (2-tailed) & $.778^{* *}$ & 1 \\
\hline **. Correlation is significant at the 0.01 level (2-tailed). & & \\
\hline
\end{tabular}

The results, as shown in Table 2, indicate that there is a significant relationship between teachers' age and the frequency of EFL teachers' code switching $(r=.67, p<.05)$. In other words, the older Iranian EFL teachers are, the more they use code switching in the classroom. Thus, the first null hypothesis of the study was rejected. Figure 1 shows the scatter plot of the relationship between teachers' age and the frequency of their code switching. 


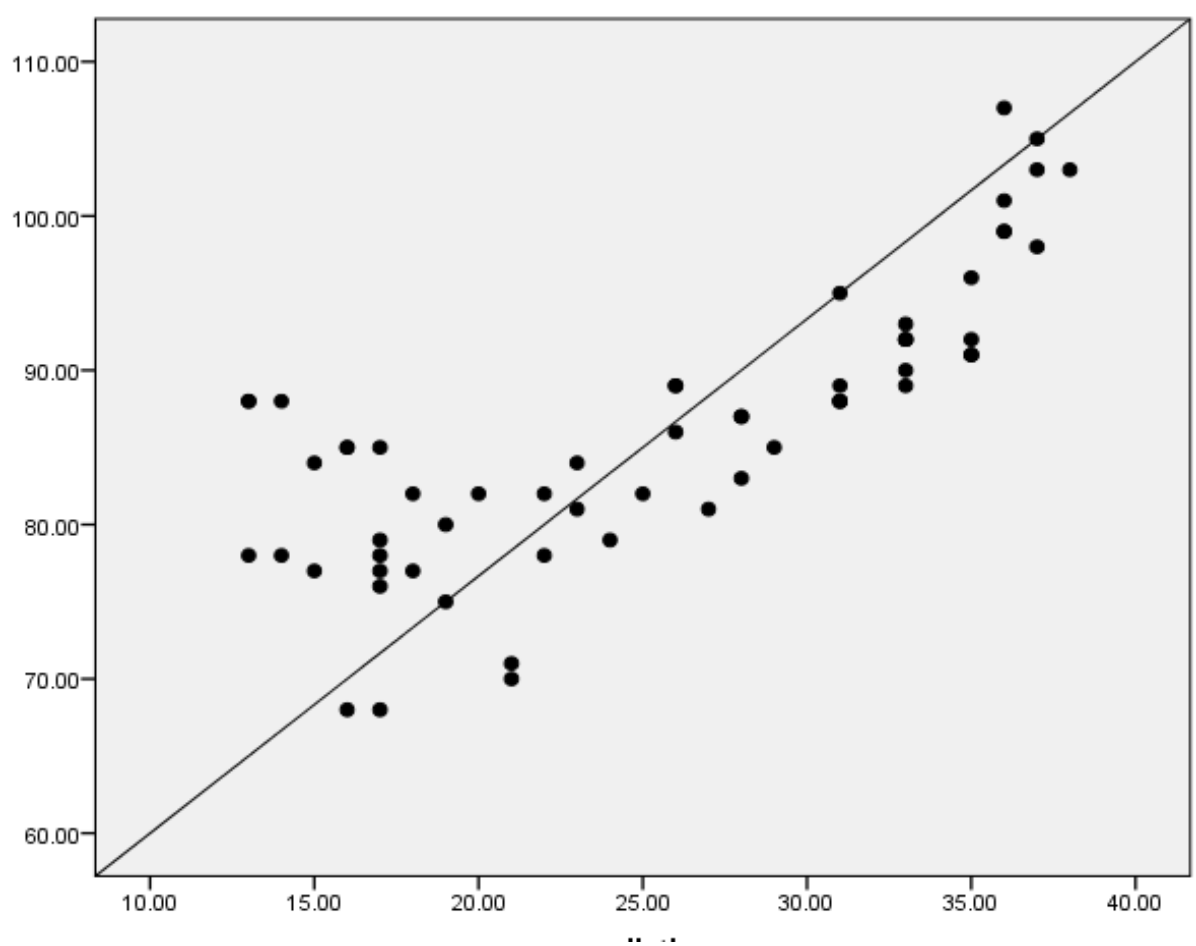

Figure 1. The scatter plot of the relationship between teachers' age and the frequency of their code switching

\subsection{Addressing the Second Research Hypothesis}

In order to investigate the second research hypothesis in finding whether there is any relationship between teachers' gender and the frequency of EFL teachers' code switching, another Pearson correlation was performed. The results of Pearson correlation are presented in Table 3.

Table 3. Pearson correlation between teacher's gender and the frequency of EFL teachers' code switching

\begin{tabular}{clcc}
\hline \multirow{2}{*}{ Gender } & Pearson Correlation & Gender & $\begin{array}{c}\text { Teachers' code } \\
\text { switching }\end{array}$ \\
\cline { 2 - 4 } & Sig. (2-tailed) & 1 & .11 \\
\cline { 2 - 4 } & $\mathrm{N}$ & 120 & .810 \\
\hline \multirow{3}{*}{$\begin{array}{c}\text { Teachers' code } \\
\text { switching }\end{array}$} & Pearson Correlation & .11 & 120 \\
\cline { 2 - 4 } & Sig. (2-tailed) & .810 & 120 \\
\cline { 2 - 4 } & $\mathrm{N}$ & 120 & 120 \\
\hline
\end{tabular}

The results, as shown in Table 3, indicate that there is no significant relationship between the teacher's gender and the frequency of EFL teachers' code switching $(r=.11, p>.05)$. Thus, the second null hypothesis of the study was accepted. 


\subsection{Addressing the Third Research Hypothesis}

The participants' level of education differed from MA to Ph.D.43 percent of teachers had MA and 57 percent had $\mathrm{PhD}$.

Table 4. Participants' Level of Education

\begin{tabular}{ccccc}
\hline & Frequency & Percent & Valid Percent \\
\hline MA & 52 & 43.33 & 43.33 \\
\cline { 2 - 5 } PhD & 68 & 56.66 & 56.66 \\
\hline Total & 120 & 100.0 & 100.0 \\
\hline
\end{tabular}

In order to investigate the third research hypothesis in finding whether there is any relationship between teachers' educational levels and the frequency of EFL teachers' code switching, another Pearson correlation was run. The results are provided in Table 5.

Table 5. Pearson correlation between teachers' autonomy and their experience

\begin{tabular}{clcc}
\hline & & Experience & Autonomy \\
\hline \multirow{2}{*}{ Experience } & Pearson Correlation & 1 & $.706^{* *}$ \\
\cline { 2 - 4 } & Sig. (2-tailed) & & .000 \\
\hline \multirow{3}{*}{ Autonomy } & Pearson Correlation & $.706^{* *}$ & 1 \\
\cline { 2 - 4 } & Sig. (2-tailed) & .000 & 120 \\
\cline { 2 - 4 } & & 120 & \\
\hline
\end{tabular}

**. Correlation is significant at the 0.01 level (2-tailed).

The results showed that there is a high, positive and significant relationship between teachers' educational levels and the frequency of EFL teachers' code switching $(r=.70, p<.05)$. In other words, the higher Iranian EFL teachers' educational level, the more they use code switching in the classroom. Thus, the third null hypothesis of the study was rejected.

\subsection{Attitudes towards code switching}

Based on the results of the interview, the usefulness of code switching strategies, especially interactive type of code switching in speaking was approved and most of the volunteering professors acclaimed that code switching can be a useful tool in helping English language teaching and learning process.

\section{Conclusion}

It is necessary for EFL teachers to be familiar with the variables affecting the process of teaching foreign language skills. One of the variables that play a role in the quality of language teaching is code switching. However, there are shortcomings of research in this field. The results of this study give credit to the usefulness of code switching strategies, especially interactive type of code switching in speaking. The success of code switching might be due to two reasons its effectiveness in learning processes of language and its role in creating a different and innovative context of language learning in comparison with 
traditional ones, both for the learners and teachers. This in turn can offer benefits for ELT contexts.

It can be inferred from the results of this study that the teachers' age and educational levels can positively influence their use of code switching strategy. In this study, gender is a non-relevant factor influencing the use or non-use of code switching in the classroom. The present study filled a gap in the relationship between teacher variables such as age, gender and educational levels which affect the quantity and quality of code switching and the frequency of code switching strategy. This interactive strategy allows EFL teachers to practice language teaching materials within a more communicative setting. To enhance learners' motivation in learning English language, teachers should attend to their discourse in the classroom while teaching and try their best to make use of all the tools available to achieve to that purpose.

Also, the findings of the present study would help EFL teachers to adopt a suitable conversational strategy in the classroom to create an atmosphere for students to engage in classroom interactions. It will be better for our teachers to be aware of students' attitudes towards their teachers' code switching behavior. This awareness may give teachers a clue to better teaching and fulfilling students' learning needs.

\section{References}

Adendorff, R. (1996). The functions of code-switching among high school teachers and students in KwaZulu and implications for teacher education. In K. Biley\& D. Nunan (Eds.). Voices from the language classroom: Qualitative research in second language education (pp. 388-406). Cambridge: Cambridge University Press.

Ariffin, K., \& Hussin, M. S. (2011). Code-switching and code-mixing of English and Bahasa Malaysia in content-based classrooms: Frequency and attitudes. The Linguistics Journal, 5(1), 220-247.

Auer, P. (2005). A postscript: Code-switching and social identity. Journal of Pragmatics, 37, 403-410. http://dx.doi.org/10.1016/j.pragma.2004.10.010

Becker, R. R. (2001). Spanish-English code switching in a bilingual academic context.Reading Horizons, 42(2), 99-115.

Blom, J. P. \& Gumperz, J. J. (1972). Social meaning in linguistic structures: Code switching in Norway. In J. J. Gumperz \& D. Hymes (Eds.).Directions in Sociolinguistics (pp. 407-434). New York: Holt, Rinehart \& Winston.

Cheng, L. R., \& Butler, K. (1989).Code-switching: a natural phenomenon vs language 'deficiency'. World Englishes, 293-309. http://dx.doi.org/10.1111/j.1467-971X.1989.tb00670.x

Chimbganda, A. B., \&Mokgwathi, T. S. (2012). Code-switching in Botswana's ESL classrooms: A paradox of linguistic policy in education. International Journal of English Linguistics, 2(2), 21-32. http://dx.doi.org/10.5539/ijel.v2n2p21 
Cook, V. (2001).Using the first language in the classroom.Canadian Modern Language Review, 57(3), 402-423. http://dx.doi.org/10.3138/cmlr.57.3.402

De Fina, A. (2007). Code switching and ethnicity in a community of practice.Language in Society, 36(3), 371-392. http://dx.doi.org/10.1017/S0047404507070182

Di Sciullo, A. M., Muysken, P., \& Singh, R. (1986).Government and code-mixing.Journal of linguistics, 22(1), 1-24. http://dx.doi.org/10.1017/S0022226700010537

Eldrige, J. (1996). Code-switching in a Turkish secondary classroom.ELT Journal, 50(4), 303-311. http://dx.doi.org/10.1093/elt/50.4.303

Greggio, S., \& Gil, G. (2007). Teachers' and learners' use of code switching in the English as a foreign language classroom: A qualitative study. Linguagem\&Ensino, 10(2), 371-393.

Gulzar, M. A. (2010). Code-switching: Awareness about its utility in bilingual classrooms. Bulletin of Education and Research, 32(2), 23-44.

Gumperz, J. J. (1982).Discourse strategies. Cambridge University Press. http://dx.doi.org/10.1017/cbo9780511611834

HamzehlouMoghadam, S., Abdul Samad, A., \&RahmaniShahraki.E. (2012).Code switching as a medium of instruction in an EFL classroom.Theory and Practice in Language Studies, 2(11), 2219-2225. http://dx.doi.org/10.4304/tpls.2.11.2219-2225

Hancock, M. (1997). Behind classroom code switching: Layering and language choice in L2 learner interaction. TESOL Quarterly, 31(2), 217-235. http://dx.doi.org/10.2307/3588045

Hill, K. D. (2009). Code-switching pedagogies and African American student voices: Acceptance and resistance. Journal of Adolescent \& Adult Literacy, 53(2), 120-131. http://dx.doi.org/10.1598/JAAL.53.2.3

Hisham Ahmad, B., \&Jusoff, K. (2009). Teachers' code-switching in classroom instruction for low English proficient learners. English Language Teaching, 2(2), 49-55. DOI: http://dx.doi.org/10.5539/elt.v2n2p49

Iannacci, L. (2008). Beyond the pragmatic and the liminal: Culturally and linguistically diverse students code switching in early-years classrooms. TESL Canada Journal, 25(2), 103-123.

Jingxia, L. (2010). Teachers' code switching to the L1 in EFL classroom.The Open Applied Linguistics Journal, 3, 10-23. http://dx.doi.org/10.2174/1874913501003010010

Kabuto, B. (2010). Code-switching during parent-child reading interactions: Taking multiple theoretical perspectives. Journal of Early Childhood Literacy, 10(2), 131-157. http://dx.doi.org/10.1177/1468798409345109

Lee, H. L. J. (2010). Code switching in the teaching of English as a second language to secondary school students.Malaysian Journal of ELT Research, 6, 1-45.

Macaro, E. (1997).Target language, collaborative learning and autonomy.Clevedon: Multilingual Matters 
Migge, B. (2007). Code-switching and social identities in the Eastern Maroon Community of

Suriname and French Guiana.Journal of Sociolinguistics, 11(1), 53-73. http://dx.doi.org/10.1080/13670050208667762

Moore, D. (2002). Case study: Code switching and learning in the classroom. International Journal of Bilingual Education and Bilingualism, 5(5), 279-293. http://dx.doi.org/10.1080/13670050208667762

Moradkhani, S. (2012). The typology of EFL teachers' code switching: A validation study. The Journal of Teaching Language Skills, 4(3), 103-126.

Moreno, E. M., Federmeier, K. D., \&Kutas, M. (2002).Switching languages, switching palabras (words): An electrophysiological study of code switching.Brain and Language, 80, 188-207. http://dx.doi.org/10.1006/brln.2001.2588

Mori, J. (2004). Negotiating sequential boundaries and learning opportunities: A case from a Japanese language classroom. Modern Language Journal, 536-550. http://dx.doi.org/10.1111/j.0026-7902.2004.t01-17-.x

Mugla, E. Ü., \&Seedhouse, P. (2005). Why that, in that language, rightnow? Code-switching and pedagogical focus.International Journal of Applied Linguistics, 15(3), 302-325. http://dx.doi.org/10.1111/j.1473-4192.2005.00093.x

Numan, D. \& Carter, D. (2001).Teaching English to speakers of other languages. Cambridge: Cambridge University Press.

Payawal-Gabriel, J. \& Reyes-Otero, M. (2006).Comprehensible input strategies and pedagogical moves using Filipino/English as medium of instruction in secondary Mathematics. Education Quarterly, 83- 97.

Poplack, S. (1980). Sometimes I will start a sentence in Spanish y termino en espan. ol: Toward a typology of code-switching.Journal of Linguistics, 22, 1-24. http://dx.doi.org/10.1515/ling.1980.18.7-8.581

Qian, X., Tian, G., \& Wang, Q. (2009).Codeswitching in the primary EFL classroom in $\begin{array}{llll}\text { China-Two case } \quad \text { studies.System, } & \text { 319-730. }\end{array}$ http://dx.doi.org/10.1016/j.system.2009.09.015

Qing, X. (2010).To switch or not to switch?Examining the code switching practices of teachers of non-English majors.Canadian Social Science, 6(4), 109-113.

Rezvani, E., \&EslamiRasekh, A. (2011). Code-switching in Iranian elementary EFL classrooms: An exploratory investigation. English Language Teaching, 4(1), 18-25. http://dx.doi.org/10.5539/elt.v4n1p18

Saxena, M. (2009).Construction \& deconstruction of linguistic otherness: Conflict \& cooperative code switching in English/) bilingual classrooms. English Teaching: Practice and Critique, 8(2), 167-187.

Simin, S., Teimouri, F., Kasmaee, H., \&Rezaei, S. (2005). The role and the effects of 
code-switching in material learning. The first national conference on research in teaching English, translation, and linguistics.

Skiba, R. (1997). Code switching as a countenance of language interference. The Internet TESL Journal, 10(8).

Turnbull, M., \& Arnett, K. (2002).Teachers' uses of the target and first language in second and foreign language classrooms.Annual Review of Applied Linguistics, 22, 204-218. http://dx.doi.org/10.1017/S0267190502000119

Weinreich, U. (1953). Languages in contact. The Hague: Mouton.

Wodak, R., Krzyzanowski, M., \&Forchtener, B. (2012).The interplay of language ideologies and contextual cues in multilingual interactions: Language choice and code-switching in European union institutions. Language in Society, 41, 157-186. http://dx.doi.org/10.1017/S0047404512000036

Woolford, E. (1983).Bilingual code-switching and syntactic theory.Linguistic Inquiry, 520-536.

Yao, M. (2011).On attitudes to teachers' code-switching in EFL classes. World Journal of English Language, 1(1), 19-28. http://dx.doi.org/10.5430/wjel.v1n1p19

Zabrodskaja, A. (2007).Russian-Estonian code-switching in the university. Arizona Working Papers in SLA \& Teaching, 14, 123-139. 